\title{
Nurses' Competencies in Providing Palliative Care for HIV/AIDS Patients in dr. Ario Wirawan Pulmonary Hospital, Salatiga
}

\author{
Desi and Yulius Yusak Ranimpi \\ Fakultas Kedokteran dan Ilmu Kesehatan \\ Universitas Kristen Satya Wacana Salatiga
}

\author{
M. Aziz Anwar \\ Rumah Sakit Paru dr. Ario Wirawan \\ Ngawen, Salatiga
}

\begin{abstract}
The aim of this research was to identify nurses' competencies (cognitive, psychomotor and affective) in providing palliative care for HIV/AIDS patients. Using narrative qualitative approach, data were collected through both structured and non-structured interviews and also direct observations on research participants. Participants in this study were nurses $(N=5)$ of dr. Ario Wirawan Pulmonary Hospital. Data were coded in accordance to aspects and interview indicators. Result showed that participants did not have information about what and how palliative care should be carried out, and also about SK Menkes No. 812/MENKES/SK/VII/2007 that is targeted at all health professionals. This influenced participants to implement both psychomotor and affective competencies related to palliative care. Factors influencing participants' lack of knowledge and competencies were personal factor, rooms' routine, time and limited human resources. HIV/AIDS patients received general care with emphasis on collaborative medical treatments.
\end{abstract}

Keywords: competency, nurse, palliative care, HIV/AIDS

\begin{abstract}
Tujuan penelitian ini ialah mengetahui kompetensi (kognitif, psikomotorik dan afektif) perawat dalam memberikan perawatan paliatif pasien HIV/AIDS. Dengan metode kualitatif naratif dilakukan pengambilan data melalui wawancara terstruktur dan nonstruktur serta observasi langsung terhadap kegiatan partisipan. Partisipan $(N=5)$ adalah perawat di RS. Paru dr. Ario Wirawan. Data dianalisis dengan proses penyandian sesuai dengan aspek/topik dan indikator yang diwawancarai. Hasil menunjukkan bahwa seluruh partisipan belum mengetahui informasi tentang apa dan bagaimana perawatan paliatif dilakukan, juga tentang SK MENKES No. 812/ MENKES/SK/VII/2007 (MenKes RI, 2007) yang sasaran pelayanannya adalah semua praktisi kesehatan. Hal tersebut memengaruhi partisipan dalam menerapkan kompetensi psikomotorik dan afektif, yang berkaitan dengan perawatan paliatif. Faktor yang memengaruhi kurangnya pengetahuan partisipan dan pengembangan kompetensinya adalah faktor personal, rutinitas ruangan, waktu, dan tenaga yang terbatas. Perawatan yang dilakukan kepada pasien HIV/AIDS tidak lebih dari perawatan biasa yang lebih mengutamakan tindakan medis kolaboratif.
\end{abstract}

Kata kunci: kompetensi, perawat, perawatan paliatif, HIV/AIDS

World Health Organization statistic in 2015 showed that the number of people with Human Immunodeficiency Virus (HIV) and Acquired Immunodeficiency Syndrome (AIDS) reached 36.7 million worldwide. This particular disease has caused 1.1 milion deaths up to the end of 2015 (WHO, 2016). In Indonesia, the total number of HIV cases was up to 150,296 people from 1987 to September 30, 2014. AIDS ca-

Correspondence concerning this article should be addressed to Yulius Yusak Ranimpi, Faculty of Health Science Universitas Kristen Satya Wacana Jl. Kartini 11A-Salatiga. E-mail: yulius.ranimpi@staff. uksw.edu ses reached 55,799 people with 9,769 death cases. Nationally, Central Java, having 9,032 people with AIDS per September 2014 and 3,767 deaths for this reason (Ditjen PP \& PL Kemenkes RI, 2014), is in the 6th position for the number of AIDS patients. Specifically, in Salatiga, from 1994 to September 2014, HIV/AIDS patients reached 213 people, consisting of 127 males and 86 females. Of this number, 53 people had died (Tribun Jateng, 2015).

The existing care for HIV/AIDS in Indonesia has only focused on medical aspect by giving antriretroviral to decelerate the growth of the virus. In most 
hospitals, the other aspects of care, namely psychological, sosial and spiritual, are often forgotten. A study by Yuanita (2016) in one of hospitals in Semarang showed that $50.8 \%$ of nurses had limited knowledge in patients' psychosocial aspects, while the rest of nurses had a good understanding on this aspect. Another study by Utami and Supratman (2005) showed $62.24 \%$ of nurses lacked the knowledge of patients' spiritual needs. These studies have shown that nurses tend to pay less attention to patients' psychosocial and spiritual needs.

Nurses play an important role in providing holistic care to their patients, it is not only limited to physical needs but also biological, psychological, social and spiritual needs. The care should be provided not only to patients but also to patients' family (The International Council, 2012). Nursing care consists of different types of care, and one of them is palliative care (Potter \& Perry, 2005).

Palliative care is defined as the care that focuses on enhancing patients' and their family's quality of life when dealing with illness. This type of care is provided as a preventive step and control of the suffering (physical, psychological, social and spiritual) of patients and their family as a result of illness (WHO, 2015). Paliative care should be carried out using inter-professional approach (involving health professsionals, such as doctors, nurses, nutritionists and others) in order to achieve the wholeness of care (holistic care). This particular care is provided to patients with active, progressive and terminal diseases, not limited only to cancer patients (Woodruf \& Doyle, 2013). One of the diseases that require palliative care is Human Immunodeficiency Virus and Acquired Immunodeficiency Syndrome (HIV/AIDS).

HIV is specifically characterised by its rapid progression in weakening the human immune system that, when it reaches to the AIDS stage, can make the patient experience death. Unfortunately, to date, HIV treatment relies heavily on the use of antiretroviral medication (ARV) that slows down the virus growth by increasing CD4 (a type of white blood cells). In the stage of AIDS, patients are easily infected by other diseases as a result of decreased immunity. Additionally, patients may suffer from physical symptoms accompanying the diseases (Hoffman, Rockstroh, \& Kamps, 2007). In addition to physical symptoms, patients may also experience impairment in psychological, social and spiritual aspects.

A publication by Sherr et al. (2011) revealed that an individual who is diagnosed with HIV/AIDS tends to suffer from post-traumatic stress disorder (PTSD).
Additionally, social issues, such as stigma and discrimination against HIV/AIDS patients and spiritual crisis as a result of PTSD, might become the burden for the patient. The existing stigma includes a belief that people with HIV/AIDS are associated with unhealthy sexual behavior and drug abuse which are still considered taboo in some cultures. Consequently, the stigma leads to discrimination where HIV/AIDS patients are considered to be immoral and potentially contagious, and therefore, should be avoided (FloromSmith \& Santis, 2012).

In performing tasks, it is important that nurses who is one of the palliative care providers understand their roles and functions. The patients of HIV/AIDS are not the only target for the care, but also patients' family. The International Council of Nurses (ICN, 2012, p. 1) explains that nurses' roles in palliative care are to minimize patients' suffering and to increase patients' (and their family's) quality of life in dying time through initial assessments, pain identification and management, as well as to help in the fulfillment of physical, social, psychological, spiritual and cultural needs. Palliative care is available in hospitals, hospices, and patients' houses.

Indonesian Government has made an effort to increase the quality of health services through the policy number 812/MENKES/SK/VII/2007 about palliative care. This policy was issued to guarantee each patient's quality of life holistically through the services provided by health professionals in health institutions, such as the Government Health Office, hospitals, community health centers (Puskesmas), hospices and other state and private health facilities. The palliative care facilities in Indonesia are available in Jakarta (dr. Cipto Mangunkusumo Hospital and Dharmais Cancer Hospital), West Java (Hasan Sadikin Hospital), Central Java (Dr. Sardjito Hospital), East Java (Dr. Soetomo Hospital), Bali (Sanglah Hospital), and Sulawesi (Dr. Wahidin Sudirohusodo Hospital).

It is important to have competencies that support palliative care. Generally, palliative care includes three basic competencies, namely cognitive, affective and psychomotor (Rutherford, 2004). Thomas (2004) stated that cognitive competency is related to nurses' knowledge of their patients and palliative care. Psychomotor competency is related to clinical skills and therapeutic communication skills; while affective competency is related to attitude, empathy and emotion of nurses before, during and after providing care. To develop these competencies, supports from theories, trainings and simulations are essential. The success in providing palliative care to patients with terminal 
diseases is often measured by patients' quality and meaning of life (Oyenka, 2010).

Considering the issues outlined above, it is important to conduct a study on nurses' competencies in palliative care, especially for HIV/AIDS patients. dr. Ario Wirawan Pulmonary Hospital (RSPAW) has always been a reference hospital for pulmonary diseases. As a result, the HIV/AIDS patients of this hospital mostly suffer from pulmonary diseases. Hence, nurses' competencies play important roles in maintaining the hospital's profile. Moreover, the patients of this hospital usually come from middle to low socioeconomic backgrounds and come from various parts of Indonesia, resulting in a variety of cultural backgrounds. Nurses should be able to carry out palliative care with sensitivity to patients from different cultural backgrounds because the care may elicit different culture-bound reactions. For HIV/AIDS patients in particular, stigma and complication of disease are the major stressors for patients. Therefore, by mastering palliative care competencies, the positive result concerning HIV/AIDS patients' quality of life could be achieved.

This present study would also assess follow-up programs related to palliative care in the community where the patients lived.

\section{Method}

This is qualitative research with a narrative approach using interview guidelines supported with voice recording devices and observation guidelines.

Five nurses, consisting of three ward nurses and two out-patient nurses, were the participants of this study. Sample was determined using purposive sampling technique with eligibility criteria as follows: participants had experiences of caring for HIV/AIDS patients in hospitals with a minimum educational level of diploma and had at least two years of working experience. The criteria were determined to ensure that participants were able to perform standard competencies of nursing care and had adapted to the work setting. Interviews were conducted on day and night shifts for the ward nurses to reveal how nurses' performances differ according to differences in work time (shifts).

The interviews were analyzed after the verbatim transcripts have been coded. The coding was done by numbering every 5th row (5th interval) in the transcript. This was conducted to ease the analysis process and discussion by quoting parts of the inter- view transcripts and adding numbers/codes behind the quotes. The chosen parts of interviews were then further analyzed. This process was applied to other themes found during coding.

The interview transcripts were grouped according to themes determined in the interview guidelines. This was performed to facilitate the process of finding new themes that could be discussed. The information that was not part of the themes, but still related to the purpose of study and problem statement, was considered as the new found theme.

Table 1 provides the examples of themes and codes from the transcripts. Data validation was conducted through triangulation with participants' colleagues and HIV/AIDS patients treated.

\section{Results}

\section{Research Participants Profile}

Table 2 is the participants' demographic profiles.

\section{Knowledge of Palliative Care}

Different responses were elicited from all participants on the question about a definition of palliative care. However, various responses from participants indicated a lack of information related to palliative care. Their answers used the words 'maybe/it seems' and 'I forget'. Further, the non-verbal behavior observed were rapid movement of eyeballs, blinking, eyes looking to the sides, staring on a particular object held (for example, a pen) and on average, participants needed about five seconds before answering the question. In addition, one participant, while crossing his/her legs, read the Ministry of Health's regulation on palliative care.

The service for HIV/AIDS patients in the out-patient department were described by two different participants. Participant 1 did not seem actively communicate health information and motivate patients. S/he focused only on taking medication and encouraging regular treatments. S/he did more writing and only looked at patients when they spoke unclearly. In contrast, Participant 2 appeared to be an active listener. S/he made an eye contact with patients, looked at patients while talking and sometimes nodded his/her head and smiled, indicating that s/he understood what patients had said. Participant 2 sat in a relaxing pose and sometimes discontinued his/her writing activity for a while. Additionally, Participant 
Table 1

Examples of Coding Process and Theme Formation

\begin{tabular}{|c|c|c|c|}
\hline Subject & Interview Transcripts & Code & Theme \\
\hline $\mathrm{N}$ & What do you think a nurse is? & 1 & \\
\hline \multirow[t]{3}{*}{$\mathrm{P}$} & A nurse is ummm.. it's kind of willingness... hahaha & & Nurse \\
\hline & $\begin{array}{l}\text { A nurse is a person who is willing to care, sincerely serving, caring for sick } \\
\text { people until they are healed. Indiscriminately... }\end{array}$ & & Competency \\
\hline & $\begin{array}{l}\text { So we have to be sincere in caring people. Basically, a nurse is..., what is } \\
\text { important is a willingness. Sick people need attention. If we treat them in vain, } \\
\text { being mean to them, they will get sicker. They will only get worse. Patients } \\
\text { come here to get better. That's the point. }\end{array}$ & 5 & \\
\hline $\mathrm{N}$ & Yes. Did you know previously about palliative care? & & Palliative \\
\hline $\mathrm{P}$ & What do you mean? & 10 & Care \\
\hline $\mathrm{N}$ & $\begin{array}{l}\text { I mean, have you ever heard of palliative care? What kind of care is it? You } \\
\text { might have heard or read about it... }\end{array}$ & & \\
\hline \multirow[t]{3}{*}{$\mathrm{P}$} & Ummm.. well.. & & \\
\hline & I might have heard of it but I forgot.. hahahaha... & & \\
\hline & I don't know which one, perhaps never..... & 15 & \\
\hline \multirow[t]{3}{*}{$\mathrm{N}$} & $\begin{array}{l}\text { All right. So palliative care is a kind of care for terminal or uncurable diseases. } \\
\text { This type of care is holistic in nature, so it does not only concern about the } \\
\text { physical side but also psychological, social and spiritual sides. It is not only } \\
\text { concern on the main symptoms of disease but also other accompanying }\end{array}$ & & \\
\hline & symptoms. & 20 & \\
\hline & $\begin{array}{l}\text { Now, if this is the description of palliative care, in your opinion, what is nurses' } \\
\text { role and how should a nurse behave? }\end{array}$ & & \\
\hline $\mathrm{P}$ & $\begin{array}{l}\text { For this kind of patient, we have to give a support. Why? Because during } \\
\text { therapy, the medical team has given support. As a nurse, our role is to care for }\end{array}$ & & $\begin{array}{l}\text { Nurse } \\
\text { Competency }\end{array}$ \\
\hline & $\begin{array}{l}\text { them. Motivate, remind them to care for their own condition. If patients are sent } \\
\text { home, they should do the same thing... }\end{array}$ & 25 & \\
\hline $\mathrm{N}$ & Do you mean providing a home care? & & \\
\hline \multirow[t]{2}{*}{$\mathrm{P}$} & $\begin{array}{l}\text { Yes, that's one. PKMRS held it here, I join it. That's where the activity takes } \\
\text { place, there are nurses too. For nurses, aside from caregiving, they also ask }\end{array}$ & & \\
\hline & $\begin{array}{l}\text { something like 'how are you?', then assess housing condition, surroundings, } \\
\text { these are all for the health of patients. Usually in the information sharing } \\
\text { session, a doctor is invited as the speaker. As for us, we go directly to the } \\
\text { patients, to their houses. Direct them on medication taking and also hygiene. }\end{array}$ & 30 & \\
\hline $\mathrm{N}$ & Does this program still run until now? & & \\
\hline $\mathrm{P}$ & $\begin{array}{l}\text { Not recently. There are community service activities instead. Homecare usually } \\
\text { involves doctors, nurses, laboratory technicians, and pharmacists. We received } \\
\text { good responses from people we visited. Because they feel like they have been } \\
\text { given attention. }\end{array}$ & 35 & $\begin{array}{l}\text { Community } \\
\text { Based Service }\end{array}$ \\
\hline $\mathrm{N}$ & Is there any hope that the home care program will continue? & & \\
\hline $\mathrm{P}$ & Oh yes. Hopefully, it will continue. & 40 & \\
\hline $\mathrm{N}$ & Also for HIV patients? & & \\
\hline $\mathrm{P}$ & $\begin{array}{l}\text { Yes, it is needed. so we need to know their living condition, we need to know } \\
\text { their real condition, we can, you know, give motivation and... well.. things like } \\
\text { that.. hehehehe.. }\end{array}$ & & \\
\hline
\end{tabular}

2 provided a brief health education about patient's illness and motivated patients to care for their health condition.

It is concluded that the nurses have not completely understand about what palliative care is and how palliative care should be carried out. During interviews, there were often inconsistencies between the questions and their given answers. For example, for a question about a definition of palliative care, the participant asked back to the interviewer about what palliative care is, instead of answering the question. Two participants indicated that they did not participate in workshops/seminars held by the hospital or other institutions. While the other two participants explained their responsibilities in patients' room. Nevertheless, several skills performed by the participants 
in caring for their patients were actually parts of palliative care. They simply did not understand the theory/concept. The participants perceived this as a part of health services (routine care) to patients.

\section{Nurse Competency}

Competency is the implementation of cognitive, psychomotor and affective aspects of nursing in the room's routines. In addition to cognitive aspect that includes nurses' understanding about palliative care, the other aspects have not been fully implemented. There were inconsistencies between verbal and nonverbal behaviors during interview and observation. The supporting fact to this observation, particularly in psychomotor aspect, was that nurses often did not say greetings, did not apologize when s/he arrived late to provide care for patients, did not compliment patients when they followed instructions, did not say thank you when patients were cooperative and waited patiently, and even, did not smile to patients. Furthermore, when delivering a treatment to patients, the nurses did not provide prior information about the procedures and the reasons for doing this. Based on the observation, there was no intensive communication between nurses and their patients.

In terms of affection, one participant was not confident in performing her/his job. The participant admitted that $\mathrm{s} /$ he did not feel comfortable with their surroundings; hence, s/he rushed in providing care to patients. The participant also admitted that $\mathrm{s} / \mathrm{he}$ was complained due to being "curt". Another participant also said that s/he was insensitive to other people. This was observed from her/his behavior when s/he came to patient's room to replace an infusion bottle, s/he avoided a small talk and merely performed her/his duty. Without waiting patients' responses, the participant returned to the nurse station.

The inconsistencies between nurses' words and behaviors could be referred to the behavioral theory by Ajzen and Fishbein in 1980, the Theory of Reasoned Action (TRA). This theory has been developed into the Theory of Planned Behavior (TPB) in 1991 (Ajzen, 1991).

The theory explains that an individual's behavior is the result of behavioral intention. Although intention is supposedly steady, it might change along with the time. The wider the time interval is, the more likely there is a change of intention. Meanwhile, intention is determined by attitude toward behavior and subjective norms.

Attitude is an evaluation on one's belief or one's affection for doing or not doing an action, which can be measured by a two-polar evaluation scale, for example good and bad, for and against, and so on. Subjective norm is one's perception on other people's normative belief that influences his/her intention of doing or not doing the considered behavior. To sum up, social pressure influences intention (Ajzen, 1985).

Based on the theory of reasoned action, the findings in this study - particularly the inconsistencies between verbal and non-verbal actions - are not related to the knowledge of palliative care that participants have not yet obtained from her/his time of study, hospital management and other media of information. The occurrence of non-verbal actions is the result of the participants' intention to perform behavior. The intention might be influenced by attitude and belief that the provided care (a part of palliative care) is a good thing to do and is good for patients who need it. The external factors, such as room routines, might also influence intention. For example, time spent for visiting a pharmacy, socializing with colleagues, completing medical records and other such activities, might result in limited time to interact with patients. In general, the behavior that occurred can be controlled, although there is no intention to do this. This is a simple explanation of the theory of planned behavior.

As mentioned earlier, the theory of planned behavior was developed from the theory of reasoned action by adding one factor that influences intention and this might have a direct effect on behavior, namely perceived behavioral control. Conceptually, perceived behavioral control exists so that actions derived from strong intentions can occur due to the existence of strong behavioral control. (Ajzen, 1991).

Perceived behavioral control refers to an individual's perception on one's ability (ease or difficulty) to act. Perceived behavioral control is determined by an individual's belief on factors that facilitate and/ or inhibit his/her actions (control beliefs), which is based on the individual's strength of feeling towards the factors mentioned (perceived power control). Generally, when the individual feels that there are more facilitating factors than the inhibiting ones for doing an action, s/he is more likely to perceive that the action is doable. In contrast, if the individual feels that there are more inhibiting factors than the supporting ones, then $s /$ he perceives that it is difficult to perform the action (Ajzen, 2006).

Facilitating and inhibiting factors might be influenced by: (a) personal aspects, such as general atti-tude, personality, life values, emotion, and intelli- 
Table 2

Participants' Profiles

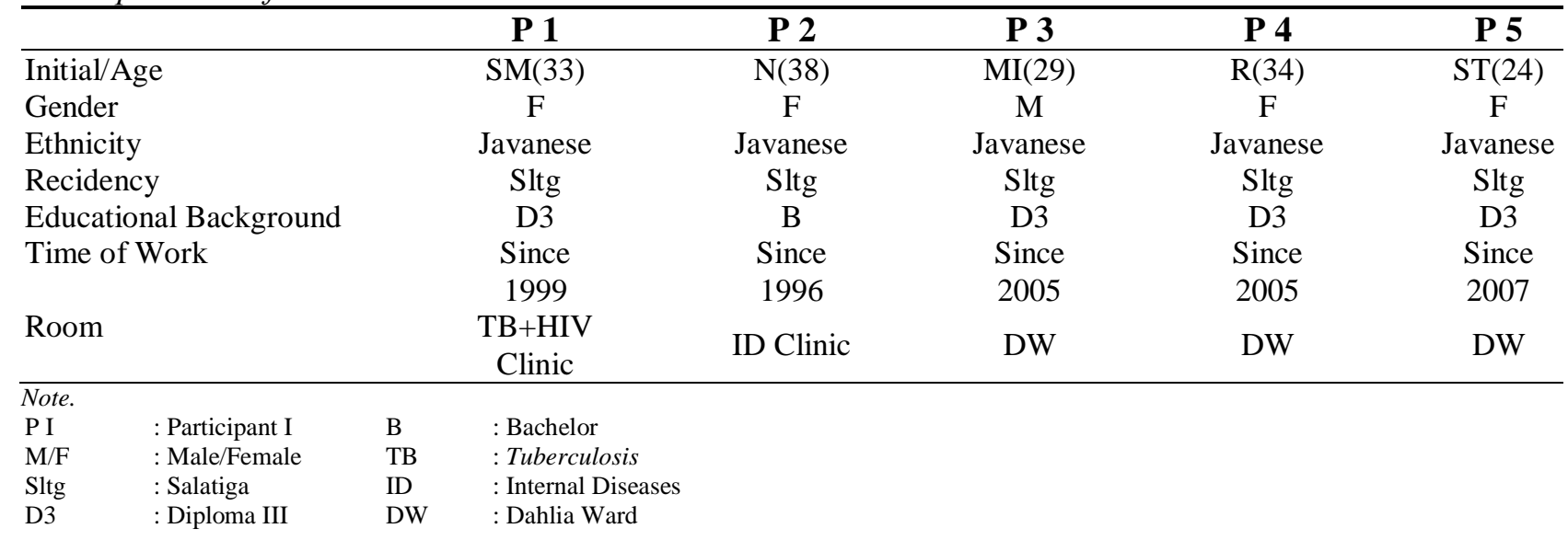

gence; (b) social aspects, such as age, gender, ethnicity, educational level, income, and beliefs or religion; (c) informational aspects, such as experiences, knowledge, and mass media (Ajzen, 2005). This might happen to the participants; in the context of this study, verbal behaviors that indicate the lack of knowledge about palliative care, nurses' role and functions, and attitude that nurses should have are the results of intention influenced by perceived control toward intelligence, knowledge and experiences. Lacking experiences and information about palliative care results in no actions related to the concept of palliative care, apart from the fact that the hospital did not provide any program related to this specific area of caring.

Next, the inconsistencies between verbal and nonverbal behaviors are related to nurses' role and functions, and attitude toward their patients. Participants' behavior might be influenced by social or personality factors (a lack of confidence). As previously elaborated, the social factors include room routine and management policy of hospital (particularly, nursing) toward executive nurses. As for the personality factors, it includes lacking confidence, sensitivity, and communication, participants' attitude that appears too "rigid" as seen from no smiling and greetings to patients, patients even perceive this behavior as "curt".

The findings on participants' actions related to palliative care that are not the results of their knowledge about palliative care, which further cause inconsistencies between verbal and non-verbal behaviors, can be explained by the theory of planned behavior. In this situation, perceived behavioral control is influenced by life values, belief, religion, emotion, experiences, educational level, knowledge, and so forth, which directs individuals to show good actions to- ward others for good reasons. For example, motivating others in need is a good action suggested by religious beliefs. This has become a part of life values/ moral acquired from family or social environment.

\section{Community Based Service}

Three out of five participants did not yet understand the concept and practice of nurses' role in discharge planning. This was shown from nurses' actions that only reviewed patients' condition and reported this to a doctor in charge if it was better so that the patients were permitted to go home. Two other participants explained their patients' condition, provided an instruction on medication intake and hospital check up as parts of discharge planning.

Two participants were aware of home care program provided by the HIV/AIDS Voluntary Counseling Test Team in a local hospital. However, both of them were not involved in the team. The VCT team consists of previous officers or senior nurses with a minimum of eight years of working experience in the hospital.

\section{Discussion}

\section{Palliative Care}

The themes discussed are related to nurses' knowledge on palliative care, implementation of palliative care and palliative care services provided by research participants. Apart from the interview results, there are components of palliative care that have been performed, for example, collaborative actions in medicating the symptomps of diseases. Meanwhile, o- 


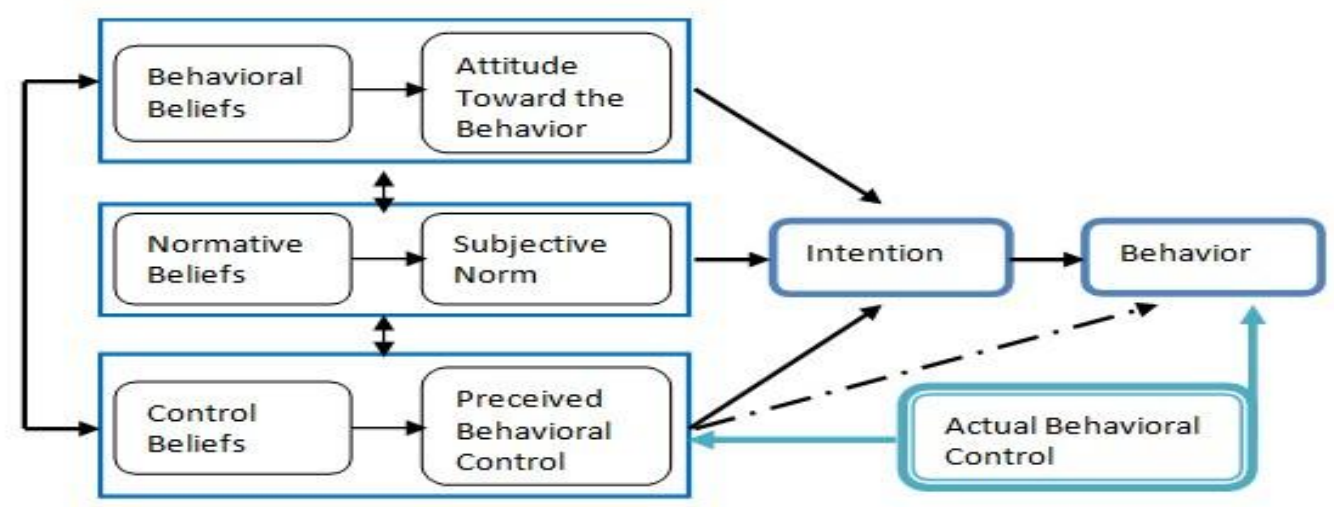

Figure 1. Ajzen's theory of planned behaviour (TPB).

ther components, such as having extensive knowledge on palliative care, having good communication skills, showing caring behaviors and so on, had not yet fully performed, and even to some extent, they were not performed at all.

The theory of planned behavior explains that the gap between nurses' cognitive and motoric aspects is plausible because of their existing attitude as a consequence of their behavioral belief that regard patients as human beings who need the care. This is universal behavior that is not limited to particular type of care. For example, the ability to listen actively, which is the requirement of palliative care. One participant failed to answer a question about nurses' actions to provide palliative care. However, in reality, the participant showed active listening skills to patients who complained about their illness. Participants reasoned that active listening is important to search for information about patients' disease. Additionally, participants believed that having someone who listens to our complaints and problems would ease our burden.

The participant's action seems to be based on his/ her attitude that being an active listener is important in order to obtain supporting data related to patients' illness. This is also related to his/her universal belief that being an active listener would provide some relief for the patients to their problems. The explanation is considered as a part of the attitude toward behavior in the theory of planned behavior.

The predisposing background for this might be a lack of knowledge on palliative care, including the fact that there was still no socialization on the National Regulation on palliative care in the hospital where the participants worked, although the regulation letter had been published and sent to all people working in the hospitals since 2007. The interview with the Head of Outpatient Division who is at pre- sent the Head of Finance is as follows:

Interviewer: "In your opinion, why the national regulation has not been fully informed to all hospital staff?"

AF: "You see, what is often happened is that the information is missing along the way. Maybe the $H R D$ in the hospital has received it. We don't know if it has been shared or not. But I think, if we are assertive, it does not really matter whether there is information or not. In fact, I have never seen the letter. Honestly, I have never seen it. If we have an HIV team, the regulation should be there, because it is our legal base for treating HIV cases".

Another factor that might influence the quality of care is the unevenness of facilities/media provided by the hospital for nurses' professional development. The facilities required were, for example, a seminar on palliative care that is compulsory for all nurses and reading materials for nurses to update and enhance their knowledge. Weber and Koehler (2017) conclude with their research that media exposure influences subjective perception, such as knowledge and ability to address issues in surroundings. Additionally, inaccurate information might influence nurses' competency, while information from liable sources might be easily understood and strengthen nurses' existing knowledge. This could be achieved by, for example, sharing recent health information to all related staff (as long as it is not confidential).

The opportunities to develop nurses' competency, particularly in regard to their knowledge, skills, attitude and emotion through seminars and workshops were lacking and limited to persons in certain positions, such as the head of ward or senior nurses. Additionally, ward nurses were also responsible for inpatients administration. This is one of the inhibiting 
factors that could influence nurses' focus of attention to their main role and responsibility as the caregiver for patients and their family.

\section{Competency}

This study found that several participants did not show initiatives to perform at their best competencies. For the question about his/her role in caring for HIV/ AIDS patients, Participant 4 responded as follows:

"Here's the condition, each person has his/her own duty here... so the psychologist is the one who interacts with patients.. we only perform our duties... so the psychologist is the only one who know patients very well.... We, we don't really know... We've just checking. So we don't know patients deeply".

The above interview excerpt shows that the competencies shown in nurses' actions are merely based on daily tasks or routines and only oriented to physical care. Meanwhile, other aspects did not seem to be considered as parts of nurses' duties. The impression of being in rush that is related to the affective competency strengthens the argument that the social interaction between participants and patients is limited.

Based on the analysis of time efficiency, morning shift routines, such as tidying patients' bed, providing medication and injection, documenting treatments and upcoming therapy programs in patients' medical records, visiting a pharmacy, taking patients for treatments or radiology assessments, and writing reports, required approximately four working hours, since the activities were conducted simultaneously. However, participants spent quite a lot of time to sit and relax while writing and had a conversation with their colleagues in the nurse station. They also spent more time on chatting in the nurse station and having snacks. Participants had never used their spare time to talk to patients or simply have a quick check on medical equipment attached to patients. This made patients and their family worried if there was something happened during their sleep.

\section{Community Based Service}

The particular themes occurred when participants mentioned about discharge planning, home care and health promotion.

Results showed that discharge planning was only regarded as a part of the routine or nurses' duties when a patient was about to go home, the nurses did not seem to have a good understanding on their specific role and responsibilities in this process. The information given on discharge planning was limited to medication and follow-up check up that patients should do after being discharged.

As for home care, this particular activity was not based on a regular schedule. For general services, the hospital coordinated only with PUSKESMAS staff in the area of patients' residence to visit and provide home care for the patients. Further, participants admitted that they had never been involved in health promotion programs held both in the hospital and in the community. A team that was specifically formed to run regular health promotion programs had only delivered two programs, namely community service activities and free medication. At the moment, the programs are no longer in place.

Promotional programs, such as health education in health institutions, were run in one-way direction. This means that the health promotion programs were delivered based only on institutional goals without involving people in the community to tailor the program according to their needs. In other words, the community was only passively involved during the events. Many health promotion programs discontinued permanently because of limited information on the community's needs towards the program.

In their research on how to build people's understanding toward Puskesmas (both related to facilities and services) as a primary health care, Mchunu and Gwele (2005) stated that community involvement in health program planning (including promoting the events) is important. The community involvement includes a collaboration, a participation, and an involvement in decision making. The results of this study can be used and adjusted by the institutions having health education or health promotion programs. Two-way interactions between a health institution and community might strengthen the system and this helps the sustainability of the programs. People in the community should not only being the receiver of the information, but also should be actively involved in sharing information related to health issues.

\section{Limitations}

This study has methodology limitations. First, in the triangulation process, the director of the hospital who is responsible in making policy and programs was not involved. This may weaken the results of 
study claiming that the hospital contributes to nurses' incompetencies in palliative care. This is because data from director of the hospital could accurately show how hospital policies and programs had been effectively carried out and well targeted. The role of the hospital management is crucial considering that the national regulation on palliative care should have been implemented by all health care providers.

\section{Conclusion}

In conclusion, this study showed that cognitively, the participants had not been exposed to information on palliative care, hence they lacked knowledge on the definition, goals and procedures of palliative care. However, based on their general knowledge on nurses' role and functions, the participants had carried out several palliative care procedures and skills directed at the HIV/AIDS patients. Only several procedures could be claimed as related to palliative care because they had not been fully implemented (involving physical, psychological, social and spiritual aspects directed to patients and their familiy). Some participants played their roles as caregivers, motivators, and information providers but they did not follow this up to the provision of home care services for HIV/AIDS patients. Two main reasons for this were the facts that firstly, all participants were not involved in health promotion programs and secondly, the limitations of the promotional team in managing the programs that resulted in the programs were shortlived and then dicontinued. In addition, the limited facilities in the hospital, work routine, time and seniority were the reasons for nurses' restrictions in receiving updated information and in developing their compencies.

\section{References}

Ajzen, I. (1985). From intentions to actions: A theory of planned behavior. In J. Kuhl \& J. Beckman (Eds.), Action-control: From cognition to behavior (pp. 11-39). Heidelberg: Springer.

Ajzen, I. (1991). The theory of planned behavior. Organizational Behavior and Human Decision Processes, 50, 179-211.

Ajzen, I. (2005). Attitudes, personality, and behavior (2nd ed.). Berkshire: Open University Press.

Ajzen, I. (2006). The theory of planned behavior. Retrieved from: http://people.umass.edu/aizen/tpb .html

Ditjen PP \& PL Kemenkes RI. Data statistik HIV di Indonesia 2014. Jakarta: Ditjen PP \& PL Kemenkes RI; 2014. p. 1-3.

Florom-Smith, A. L., \& Santis, J. P. (2012). Exploring the concept of HIV-related Stigma. Nursing Forum, 47(3), 153-165. http://dx.doi.org/10.1111 /j.1744-6198.2011.00235.x

Hoffmann, C., Rockstroh, J. K., \& Kamps, B. S. (Eds.). (2007). HIV Medicine 2007 (15th ed.). Cagliari, Paris: Flying Publisher.

International Council of Nurses/ICN. (2012). Nurses' role in providing care to dying patients and their families. Retrieved from http://www.icn.ch/ images/stories/documents/publications/position_s tatements/A12_Nurses_Role_Care_Dying_Patien ts.pdf

Mchunu, G., \& Gwele, N. (2005). The meaning of community involvement in health: The perspective of primary health care communities. Curationis, 28(2), 30-37. http://dx.doi.org/10.4102/cura tionis.v28i2.943

Menteri Kesehatan RI. (2007). Keputusan Menteri Kesehatan Republik Indonesia No. 812/Menkes/ SK/VII/2007 Tentang Kebijakan Perawatan Paliatif. Jakarta: Penulis.

Onyeka, T. (2010). Psychosocial issues in palliative care: A review of five cases. Indian Journal of Palliative Care, 16(3), 123-128. http://dx.doi.org/10. 4103/0973-1075.73642

Potter, A. P., \& Perry, A. G. (2005). Fundamental keperawatan: Konsep, proses dan praktik (4th Ed., Vol. 2). M. Ester, D.Yulianti, \& I. Parulian (Translation.). Jakarta: EGC.

Rutherford, J. (2004). Key competencies in the New Zealand curriculum: A snaphost of consultation (Unpublished paper). Ministry of Education, Wellington, New Zealand. Retrieved from http://www. nzcurriculum.tki.org.nz

Sherr, L., Nagra, N., Kulubya, G., Catalan, J., Claudine Clucasand, C., \& Harding, R. (2011). HIV infection associated post-traumatic stress disorder and post-traumatic growth - A systematic review. Psychology, Health \& Medicine, 16(5), 612-629. http:// dx.doi.org/10.1080/13548506.2011.579991

Thomas, K. (2004). Learning taxonomies in the cognitive, affective and psychomotor domain. Retrieved from www.rockymm/whitePapers/rma-wp-le arning-taxonomies.pdfountainalchemy.co

Tribun Jateng. (04 Desember, 2015). Retrieved from http://jateng.tribunnews.com/2015/12/04/soviemendata-penderita-hiv-aids-di-salatiga-mencapai- 
213-orang

Utami, Y. W., \& Supratman. (2009). Hubungan antara pengetahuan dengan sikap perawat dalam pemenuhan kebutuhan spiritual pasien di BRSUD Sukoharjo. Berita Ilmu Keperawatan, 2(2), 69-74.

Weber, M., \& Koehler, C (2017). Illusions of knowledge: Media exposure and citizens' perceived political competence. Journal of communication, 11, 2387-2410. http://dx.doi.org/1932-8036/20170005

WHO/World Health Organization. (2015). WHO definition of palliative care. Retrieved from http:// www.who.int/cancer/palliative/en/
WHO/World Health Organization. (2016). HIV/AIDS. Retrieved from http://www.who.int/features/qa/ 71/en/ Woodruf, R., \& Doyle, D. (2013). The IAHPC manual of palliative care ( $3 \mathrm{rd}$ ed.) Houston-Texas, USA: IAHPC Press. Accessible at http://hospice care.com/about-iahpc/publications/manuals-guide lines-books/manual-of-palliatice-care

Yuanita, O. (2016). Pengetahuan perawat dalam aspek psikososial di ruang rawat inap penyakit dalam RS Islam Sultan Agung Semarang (Unpublished manuscript). Universitas Muhammadiyah Semarang. 